\title{
Immunohistochemical Observations on the Localization of Calmodulin in the Chicken Ovary
}

\author{
Yukinori Yoshimura, Toshikazu Oкамото \\ and Tatsudo T AmURA \\ Faculty of Applied Biological Science, Hiroshima University, \\ Higashi-Hiroshima 724, Japan
}

\begin{abstract}
Calcium is required for steroidogenesis and contraction of follicular wall at ovulation. The aim of this study was to determine the localization of calmodulin in the ovary of laying hens by immunohistochemistry. It is expected that calmodulin would be found in the tissues that contain calcium. Dense immunoreactive products showing the presence of calmodulin were observed in the granulosa cells and thecal interstitial cells of yellow large follicles and in the interstitial cells of small follicles and stroma. Dense reaction products were also observed in the smooth muscle bundles and in the thecal fibroblasts of yellow large follicles. The presence of calmodulin in steroidogenic and contractile tissues suggests that calcium and calmodulin system is involved in steroidogenesis and contraction of the follicular wall.
\end{abstract}

(Jpn. Poult. Sci., $27: 356-362,1990)$

Key words : ovary, calmodulin, steroidogenic cells, contractile cells

\section{Introduction}

The main functions of chicken ovary are steroidogenesis and ovulation. It has been reported that calcium ions are required for steroidogenesis which is stimulated by gonadotropins ${ }^{1,2)}$. On the other hand, the follicular wall has contractile activities which increase the tension of the wall and promote follicular rupture ${ }^{3)}$. Calcium ions may also play an important role in the contraction of follicular wall because calcium is essential for the contraction of many kinds of cells ${ }^{4)}$. In many cellular functions, the effects of calcium are mediated by calmodulin which is one of the intracellular high affinity calcium-binding proteins ${ }^{5)}$. Therefore, it is expected that the action of calcium on steroidogenesis and contraction of the follicular wall is also mediated by calmodulin. However, to our knowledge, there are no reports on the distribution of calmodulin in the chicken ovary. Therefore, we designed the present experiment to confirm the presence of calmodulin at the sites where calcium plays a role in steroidogenesis and contraction of the follicular wall. The localization of calmodulin in the ovary was examined by an immunohistochemical method.

\section{Materials and Methods}

\section{Tissue preparation}

A total of five White Leghorn hens laying 4 eggs or more in a sequence, 
maintained in individual cages under $14 \mathrm{hrs}$ light regimen and provided with food and water ad libitum were used in this study. The birds were killed about $3-5 \mathrm{hrs}$ after oviposition and the ovary was removed. The tissues of ovarian stroma (containing small follicles), the yellow large follicles (the largest to forth largest follicles) and the ruptured follicle (28 hrs after ovulation) were fixed in 10\% phosphate-buffered formalin for $24 \mathrm{hrs}$. After rinsing in phosphate-buffered saline (PBS), tissues were dehydrated in graded ethanol and xylene, and embedded in paraffin $\left(54^{\circ} \mathrm{C}\right)$. Sections of $6 \mu \mathrm{m}$ thick were prepared and used for hematoxylin-eosin staining and immunohistochemical localization of calmodulin.

\section{Antibodies}

Anti-calmodulin serum, an immunoglobulin fraction of antiserum produced in goat by injections of purified bovine brain calmodulin, was obtained from Bio-Makor (Israel). The specificity of the antibody to calf calmodulin has been examined by immunoblot and the counter immunoelectrophoresis method. The appropriateness of the antiserum for immunohistochemical detection of avian calmodulin has been determined. Biotinylated rabbit anti-goat immunoglobulins and avidin-peroxidase complex (StraAviGen immunohistology kit) were obtained from Bio Genex Lab., CA, USA.

\section{Immunostaining}

After deparaffinization and rehydration in PBS, sections were treated successively with $3 \%$ normal rabbit serum for $30 \mathrm{~min}$ and the primary antiboby (anti-calmodulin serum at a dilution of $1: 100$ in PBS) for $1 \mathrm{hr}$ at room temperature. After rinsing the section in PBS, sections were incubated first in biotinylated antigoat IgG for $30 \mathrm{~min}$ followed by incubation in avidin-peroxidase complex for $30 \mathrm{~min}$ at room temperature. Sections were washed in PBS after each incubation. Sections were finally treated for about $3 \mathrm{~min}$ with $0.02 \% 3,3^{\prime}$-diaminobenzidine tetrahydrochloride (DAB, Nakarai Chem., Tokyo) in $0.05 \mathrm{M}$ Tris- $\mathrm{HCl}$ buffer ( $\mathrm{pH} 7.6$ ) containing $0.01 \%$ hydrogen peroxide. Sections were then washed in tap water, dehydrated, cleaned and covered. Control sections for non-specific reaction were prepared identically except for replacing the primary antibody with non-immune goat serum.

\section{Results}

Immunoreactive products showing the presence of calmodulin were observed in almost all types of cells in the ovary, although the intensity varied greatly. Staining of the nuclear envelope was sometimes observed, but this was not observed in control sections. Figure 1 shows a small follicle (approximately $1 \mathrm{~mm}$ diameter) embedded in the ovarian cortex. Dense reaction products were observed in the granulosa cells enclosing the ovum. The ovum contained moderate amounts of the reaction products. Figure 2 presents the wall of white small follicle (approximately $3 \mathrm{~mm}$ diameter) which contains the stratum granulosum and thecal tissue. Dense reaction product could not be found in the granulosa cells in these follicles. Interstitial cells distributed in the thecal layer contained dense granular reaction products in the cytoplasm. Figure 3 shows the distribution of reaction products in the third largest 
follicle which is in a rapid growth phase. The thecal layer of these rapidly growing follicles is divided into two layers, theca interna and theca externa. The theca interna contains the interstitial cells and the theca externa consists of dense fibrous connective tissue. Dense reaction products were observed in the cytoplasm of granulosa and thecal interstitial cells. Staining of the nuclear envelope was prominent in these cells. The thecal fibroblasts contained a moderate amount of reaction products. The same results were obtained in the other yellow large follicles including the fourth largest to the largest follicles. In the ruptured follicle approximately $28 \mathrm{hrs}$ after ovulation, no dense reaction products were observed in any types of cells except for a slight staining of nuclear envelope (Fig. 4).

Interstitial cells distributed throughout the stromal tissue contained granular reaction products in their cytoplasm (Fig. 5). Moderately dense reaction products were also observed in the smooth muscle bundles which originate from the ovarian stroma and distributed in the loose connective tissue (between the theca externa and surface epithelium) of the yellow large follicles (Fig.6). In control sections, no reaction products of $\mathrm{DAB}$ could be found, suggesting that the reaction products in experimental sections were specific for calmodulin (data is not shown).

\section{Discussion}

The main findings of this study which examined the localization of calmodulin in the chicken ovary by immunohistochemistry are : 1) granulosa cells in the yellow large follicles and less yolky small follicles (less than $1 \mathrm{~mm}$ diameter) contained a greater amount of calmodulin than did small white follicles (1 to $5 \mathrm{~mm}$ diameter) and the ruptured follicles ( $28 \mathrm{hrs}$ after ovulation ) ; 2) the interstitial cells in both stroma and thecal layer contained a large amount of calmodulin ; 3 ) the thecal fibroblasts and smooth muscle fibers in the loose connective tissue of follicles and stroma showed a dense distribution of calmodulin.

\section{Explanation of Figures}

Fig. 1. Immunoreactive products to calmodulin in a less yolky small follicle (approximately $1 \mathrm{~mm}$ diameter). Note the dense reaction product in the granulosa cells. ov: ovum, sg: stratum granulosum, st: stroma. Scale bar $=25 \mu \mathrm{m}$.

Fig. 2. Immunoreactive products to calmodulin in a small white follicle (approximately $3 \mathrm{~mm}$ diameter). Note the reaction products in the interstitial cells (arrows). No dense reaction product is present in the stratum granulosum (sg). ov: ovum, $\mathrm{t}$ : theca. Scale bar $=25 \mu \mathrm{m}$.

Fig. 3. Immunoreactive products to calmodulin in the third largest yellow follicle. Note the dense reaction products in the granulosa cells (arrow heads) and thecal interstitial cells (arrows), and moderate amount of reaction products in the fibroblasts of the theca externa (te). $\mathrm{sg}$ : stratum granulosum, ti : theca interna, y: yolk. Scale bar $=25 \mu \mathrm{m}$.

Fig. 4. Immunoreactive products to calmodulin in a ruptured follicle $(28 \mathrm{hrs}$ after ovulation). No dense reaction products are present except for a slight staining of nuclear envelope. sg : stratum granulosum, ti : theca interna, te : theca externa. Scale bar $=25 \mu \mathrm{m}$. 

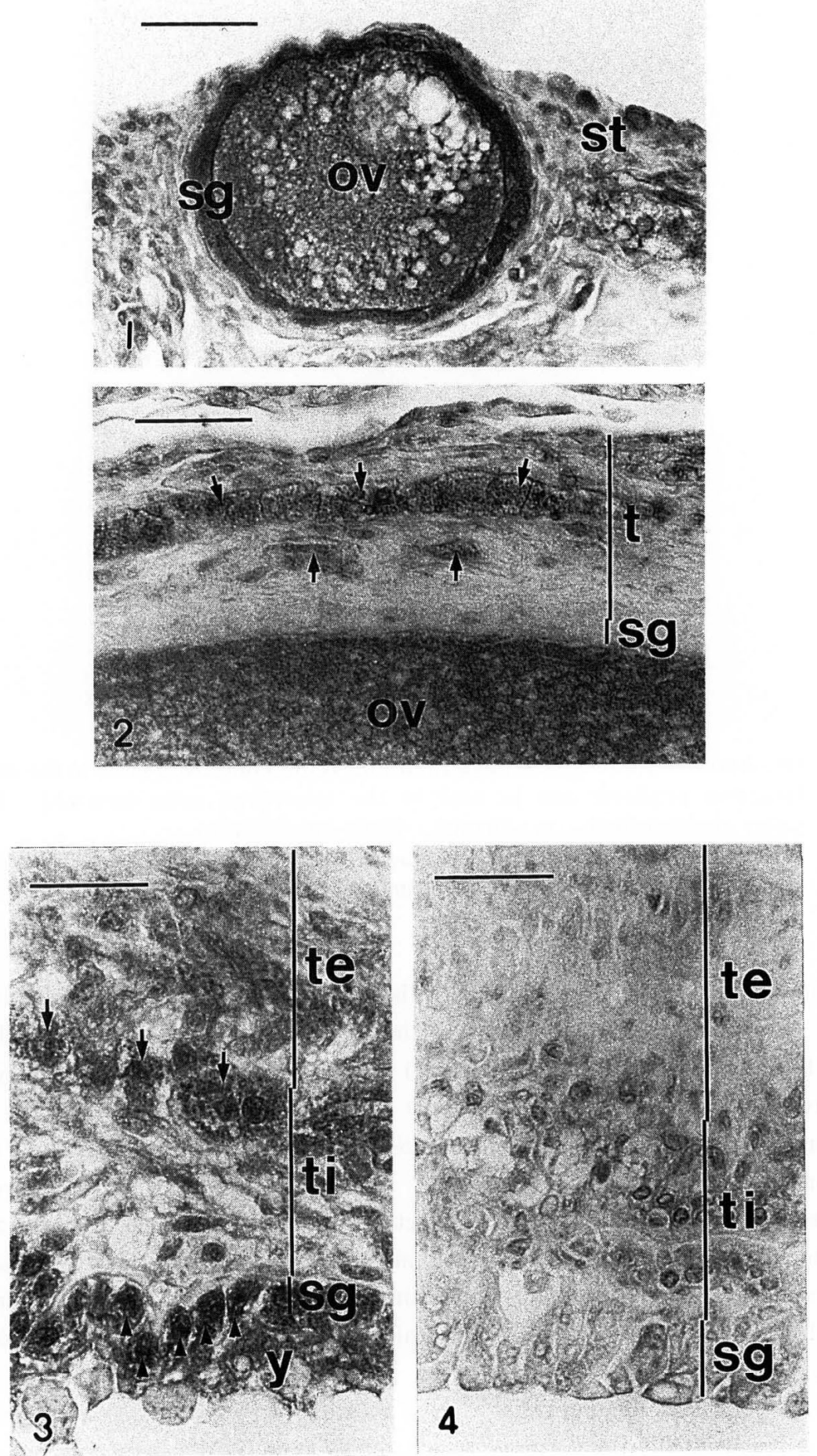


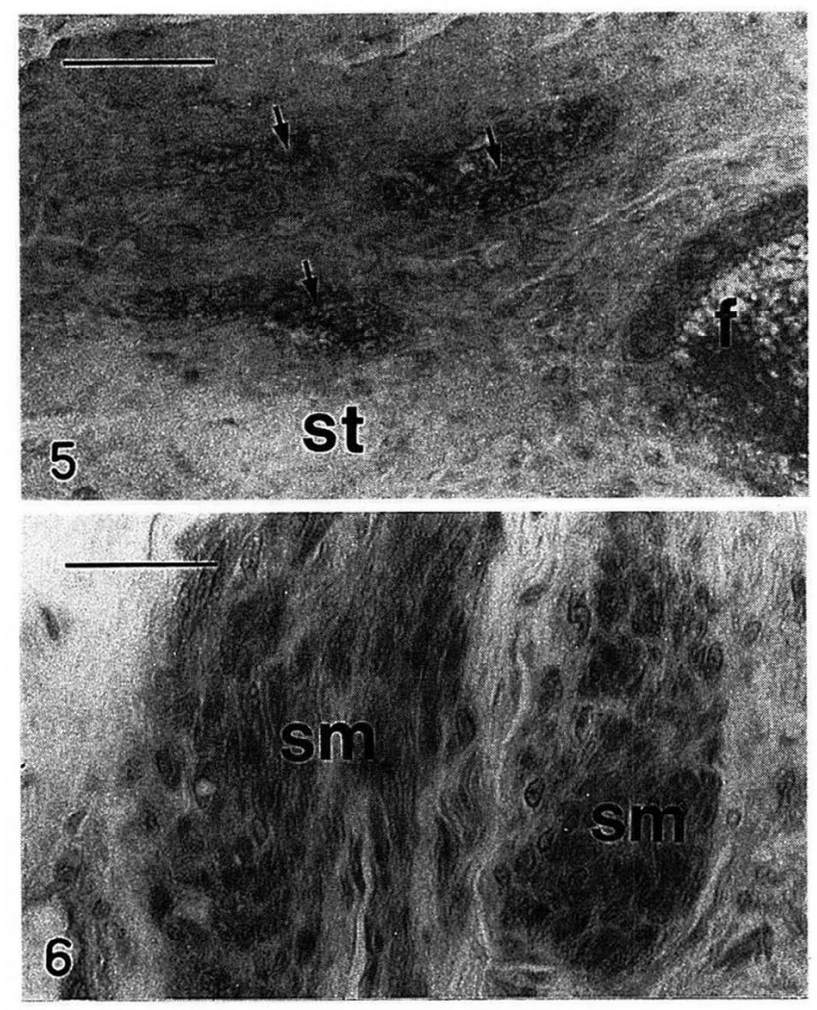

Fig. 5. Immunoreactive products to calmodulin in the interstitial cells in the stroma. Reaction products can be seen in the interstitial cells (arrows). f: less yolky small follicle. st: stroma. Scale bar $=25 \mu \mathrm{m}$.

Fig. 6. Immunoreactive products to calmodulin in the smooth muscle fibers in the stroma. Smooth muscle fibers $(\mathrm{sm})$ contain the reaction products. Scale bar $=25 \mu \mathrm{m}$.

In the chicken ovary, the granulosa cells as well as stromal and thecal interstitial cells are the steroid producing cells ${ }^{6}$. It is suggested that the granulosa cells in the smaller follicles (less than $5 \mathrm{~mm}$ diameter) do not have steroidogenic activity because $3 \beta$-hydroxysteroid dehydrogenase activity cannot be detected in these cells ${ }^{7,8)}$. The progesterone producing activity of granulosa cells increases as the follicles approach ovulation and decreases after ovulation ${ }^{6)}$. The interstitial cells in both stroma and theca produce mainly estrogens ${ }^{6}$. Collectively, the localization of calmodulin in active steroidogenic cells suggests that calmodulin levels are positively correlated with the steroidogenic activity of cells. Therefore, it can be concluded that the calcium and calmodulin system is involved in the steroidogenesis of the granulosa cells of yellow large follicles and the interstitial cells. This observation supports the previous reports by ASEM and HERTELENDY ${ }^{1,2)}$ who indicated that the continuous presence of calcium is essential for the hormone regulation of progesterone synthesis by acting at multiple sites both proximal and distal to cAMP generation in chicken granulosa cells. Immunoreactive staining of nuclear envelope was distinct in granulosa cells and interstitial cells of yellow large follicles, which may be the result of gonadotropin 
stimulation. HARPER et al. ${ }^{9)}$ found that amount of calmodulin in nuclei of the adrenal cortex was greatly increased by the injection of corticotrophin into the rat. The reason for the presence of a large amount of the calmodulin in the granulosa cells of less yolky small follicles which are not active steroidogenic cells remains to be elucidated.

The follicular wall contains two kinds of contractile cells, namely smooth muscle cells and thecal fibroblasts which have contractile activity ${ }^{3)}$. Smooth muscle bundles are distributed in the loose connective tissue. The thecal fibroblasts have a large number of microfilaments ${ }^{10)}$, actin ${ }^{11)}$ and $\operatorname{myosin}^{12)}$ in their cytoplasm and show the contractile activity in vitro ${ }^{3)}$. A large amount of calmodulin was localized in both smooth muscle cells and thecal fibroblasts. It is well established that calcium and calmodulin system is involved in the contraction mechanism of smooth muscle $e^{4)}$ The results of this study suggest that calcium and calmodulin system is involved in the contractile mechanism not only of smooth muscle cells in the loose connective tissue but also of the thecal fibroblasts.

In conclusion, our results suggest that calcium and calmodulin system is involved in steroidogenesis in granulosa and interstitial cells and in contraction of follicular wall.

\section{Acknowledgements}

We thank Dr. Janice M. BAHR, University of Illinois, Urbana, IL, for her reviewing this manuscript.

\section{References}

1) Asem, E.K. and F. Hertelendy (1986) Role of calcium in luteinizing hormoneinduced progesterone and cyclic AMP production in granulosa cells of the hen (Gallus domesticus). Gen. Copm. Endocr., 62:120-128.

2) Asem, E.K. and F. Hertelendy (1986) Trifluoperazine inhibits progesterone and cyclic AMP production in granulosa cells of the hen (Gallus domesticus). Gen. Comp. Endocr., 64 : 107-111.

3) Yoshimura, Y., K. Tanaka and O. Koga (1983) Studies on the contractility of follicular wall with special reference to the mechanism of ovulation in hens. $\mathrm{Br}$. Poult. Sci., 24 : 213-218.

4) Dabrowska, R., J.M.F. Sherry, D.K. Aromatori and D.J. Hartshorne (1978) Modulator protein as a component of the myosin light chain kinase from chicken gizzard. Biochemistry, $17: 253-258$.

5) Cheung, W.Y. (1982) Calmodulin: An overview. Fed. Proc., $41: 2253-2257$.

6) Wells, J.W. and A.B. Gilbert (1984) Physiology and Biochemistry of the Domestic Fowl, (Freeman B.M. ed.) : vol. 5, pp. 323-343, Academic Press, London.

7) Davidson, M.F., A.B. Gilbert and J.W. Wells (1979) Activity of ovarian $\Delta^{5}-3 \beta-$ hydroxysteroid dehydrogenase in the domestic fowl (Gallus domesticus) with respect to age. J. Reprod. Fert., $57: 61-64$.

8) Yoshimura, Y., T. Окамото and T. Tamura (1989) Enzyme histochemical observations on the ovarian small follicles in relation to the mechanim of atresia in laying hens (Gallus domesticus). Jpn. Poult. Sci., 26 : 10-16.

9) Harper, J.F., W.Y. Cheung, R.W.Wallace, H.- L. Haung, S.N. Levine and A.L. Steiner (1980) Localization of calmodulin in rat tissues. Proc. Natl. Acad. Sci., 77 : $366-370$. 
10) Perry, M.M., A.B. Gilbert and A.L.Evans (1978) Electron microscope observations on the ovarian follicle of the domestic fowl during the rapid growth phase. J. Anat., 125 : 481-497.

11) Yoshimura, Y., T. Окамотo and T. Tamura (1988) Distribution of actin in the ovarian follicular wall of the chicken. Jpn. Poult. Sci., $25: 218-221$.

12) Unsicker, K., F. Seidel, H.-D. Hofmann, T.H. Mūller, R. Schmidt and A. Wilson (1983) Catecholaminergic innervation of the chickn ovary with special reference to the follicular wall. Cell Tiss. Res., $230: 431-450$.

\section{鶏卵巣におけるカルモデュリン分布の免疫組織化学的観察 \\ 吉村幸則・岡本敏一・田村達堂 \\ 広島大学生物生産学部 東広島市 724}

卵宩内のステロイドホルモン産生過程および排卵時の 卵胞壁収縮にはカルシウムイオンが必要である。本実験 の目的はカルシゥム結合蛋白質であるカルモデュリンの 産卵鶏卵巣内分布を免疫組織化学的に明らかにすること である。カルシゥムイオンを必要とする組織にはカルモ デュリンが分布するものと推定される。多量のカルモデ ユリンの存在を示す濃い免疫反応産物が黄色大卵胞の顆 粒層細胞と卵胞膜間質細胞さらに小卵胞と卵宩実質に分 布する間質細胞に認められた。さらに同免疫反応産物は
卵巣内平滑筋束および黄色大卵胞の卵胞膜線維芽細胞に あ認められた。ステロイド産生細胞および収縮性細胞に おける多量のカルモデュリンの存在から, 卵巣内ステロ イドホルモン産生および卵胞壁收縮におけるカルシウム イオンの役割にはカルモデュリンが関与するむのと推定 された。

（家禽会誌， $27 ： 356 ３ 62 ， 1990 ）$ キーワード：卵巣，カルモデュリン，ステロイド産生細 胞, 収縮性細胞 